\title{
The Influence Of Social Media On Buying Decisions On Women Small And Medium Enterprises (MSMEs) In North Sumatera
}

\author{
Fivi Rahmatus Sofiyah \\ Management Department \\ University Of Sumatra Utara \\ Medan, Indonesia \\ fivirahmatus2017@yahoo.com
}

\author{
Yulinda \\ Management Department \\ University Of Sumatra Utara \\ Medan, Indonesia
}

\begin{abstract}
The purpose of this research is to know the influence of social media usages such as Facebook, Instagram, WhatsApp, Line, and Twitter on buying decisions Women MSMEs in North Sumatra from 2015 until 2016. This research is descriptively quantitative method with the purposive sampling as many as 100 Women MSMEs in North Sumatra. Primary data collection is used through questionnaires, interview, observation, and documentation as well. The secondary data is got from library research, text book, government institution, and journal review. Multiple correlation regression and path analysis is used to see the influence with the instrument of SPSS 16. The result of the research is Social media is Facebook, and WhatsApp have a significant effect on the marketing of MSMEs. However, Instagram, Line, and Twitter have no significant effect on the marketing of MSMEs and Social media such as Instagram and Line and the marketing of MSMEs have a significant effect on buying decision. However, Facebook, WhatsApp, and Twitter have no significant effect on buying decision Women (MSMEs) In North Sumatra.
\end{abstract}

\section{Keywords—social media; woman; buying decision}

\section{INTRODUCTION}

The ease of information dissemination and increasingly market mechanism competition has increased consumer awareness of the wide selection of products and services to choose from. If MSMEs do not fix the marketing strategy to increase sales, They will be threatened with bankruptcy. They need to see various potential of media alternative to become marketing media. One potential that can be utilized is information technology that makes people no longer question the limit of distance, space and time.

Information technology brought the progress of internet, it offers many benefits for MSMEs to improve the marketing of its products. In addition, it provides the benefits of increasing the opportunities for them to cooperate with other entrepreneurs. One of the Internet technology that is growing rapidly and very potential to encourage the marketing of
MSMEs is social media. Social media has the potential to connect many people easily and for free.

Marketing with promotional strategies through the internet especially with social media (social networking) can increase sales widely and does not require expensive marketing costs. Consumers will also find it easier to find information about the products they want to buy because they do not need to meet directly.

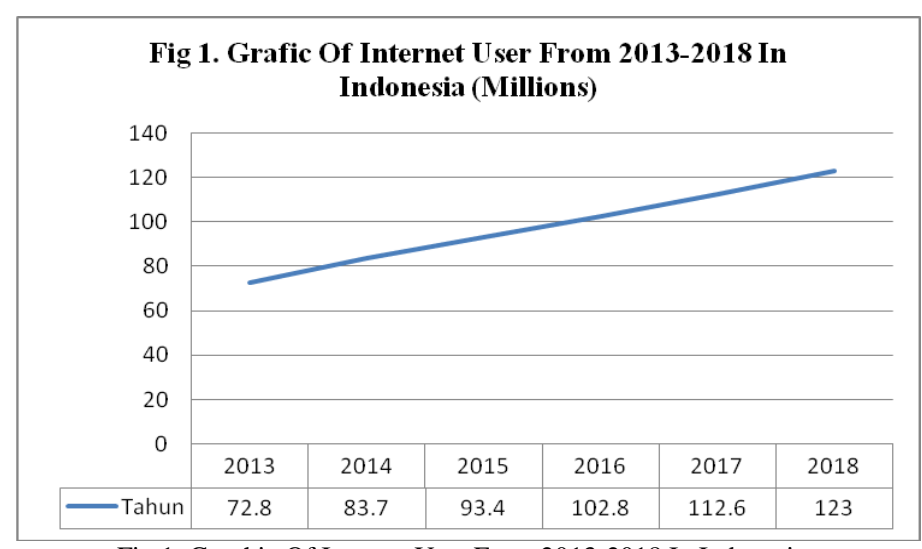
Source: [1]

Fig.1. Graphic Of Internet User From 2013-2018 In Indonesia

The netter population of the country reaches 83.7 million people by 2014. The rate that applies to every person who accesses the internet at least once per month puts Indonesia at the 6th largest in the world in terms of the number of internet users In 2017, e-Marketer estimates netter Indonesia will reach 112 million people, beating Japan in the fifth rank of the growing number of Internet users more slowly. Overall, the number of internet users worldwide is projected to reach 3 billion people by 2015. Three years later, by 2018, an estimated 3.6 billion people on Earth will access the internet at least once every month [1].

The Appropriate social media use can improve the image of a company based on consumer point of view. The strength of a company's social media is built on the pleasure, hobbies, lifestyle, loyalty, and curiosity of the consumers themselves. 
These things affect consumer purchasing decisions. If consumers already understand very well about the interesting products, then they will immediately notify the friends or the people around him. What is expected of course affects them to make a buying decision.

Situational factor that can influence on consumer buying process consists of five categories; the first one is physical surrounding like location, store ambiance, or weather. Second is social surrounding like characteristics and interactions with others. Third is the time dimension [2].

Social Influence as important factors which contribute to the purchase decision of the Smartphones. However, it has been noted that price is not a key concern for the people using Smartphones. The reason might be that the convenience provided by the Smartphone is worthy enough, to pay even a little higher for a Smartphone [3].

Most previous studies focused on investigating the influences of lifestyle and money attitude on purchase decision making independently, and few explored the influence of these two factors on purchase decision making simultaneously. Studies examining the moderating effect of personal values in the influence of lifestyle and money attitude on purchase decision making are even rarer, and this has been the main motivation for the investigation of this particular topic in this study [4].

Family purchase behavior is a research field of special interest for firms and institutions. The democratization of society and family has led to changes in the way that both society and household members understand genders [5].

This research shows that advancements on the internet and the emergence of Web 2.0 along with social media have empowered customers. In this climate, consumers create added value through collaboration and social interactions on the internet. They support the business through the cocreation of value via their social interactions [6].

Electronic Marketing (E-Marketing) can be viewed as a new philosophy and a modern business practice involved with the marketing of goods, services, information, and ideas via the internet and other electronic means. By reviewing the relevant literature, it is noticed that definitions of electronic marketing (E-Marketing) vary according to each author's point of view, background, and specialization [7].

Marketing is a societal process, which discerns consumer's wants, focusing on a product or service to fulfill those wants, attempting to mold the consumers toward the products or services offered. With change in time, marketing also affected positively with advance technology. E-marketing has added thrill in marketing professionals.
This paper aims to provide an overview of Traditional Marketing and E-Marketing with their pros and cons [8].

The way in which digital marketing has developed since the 1990s and 2000s has changed the way brands and businesses utilize technology and digital marketing for their marketing. Digital marketing campaigns are becoming more prevalent as well as efficient, as digital platforms are increasingly incorporated into marketing plans and everyday life, and as people use digital devices instead of going to physical shops [9].

The revolution of information technology (IT) and communications has changed the way people conduct business today. Nowadays, most of the businesses are related to electronically instruments especially internet [10].

The essence of the "product" element in e-commerce corresponds partly to the essence of the traditional element concept. By creating additional opportunities for the development of electronic distribution channels, the virtual environment promotes production of commodities and consumer goods, which are to a greater or lesser extent in demand among online consumers [11].

Other potential participants include advertising agencies that help generate and place the advertisement copy, the advertisement server who technologically delivers the advertisement and tracks statistics and advertising affiliates who do independent promotional work for the advertiser [12].

Online marketing offers an enormous amount of possibilities for companies. It is an evolving world which is why constant development of strategies is necessary. It is much easier for customers to find substitutes from competitors on the internet because of the minimal effort a person has to make to get to another website [13].

Some of the disadvantages of e-Marketing are dependability on technology, Security, privacy issues, Maintenance costs due to a constantly evolving environment, Higher transparency of pricing and increased price competition, and worldwide competition through globalization [14].

\section{RESEARCH METHODOLOGY}

The technique of collecting data in this research using questioner. Questionnaire is a data collection technique that is done by giving a set of written questions to respondents to answer. Questionnaires are used to find out the opinions of respondents. In this case the respondent only responded by checking the alternative answer provided. Questionnaires were given to respondents directly.

The technique used in the determination of research samples is purposive sampling technique that is sampling 
research based on certain criteria. The sample used in this research is 100 actors of Women MSMEs who use social media in the marketing process of their business. Women MSMEs who became the focus of this research is based in: Medan, Binjai, Sibolga, Tebing Tinggi and Siantar. The analysis method used is Multiple Linear Regression and Path Analysis. For path analysis is used to see the effect of independent variables on the dependent variable directly or indirectly.

\section{RESULTS AND DISCUSSION}

\section{A. Classic assumption test}

\section{Normality test}

In the Fig.2 Graphical normality test results using the P-P plot it appears that the dots spread around the diagonal line and its distribution follows the direction of the diagonal line. It shows that the regression model is worthy of use because it meets the normality assumption.

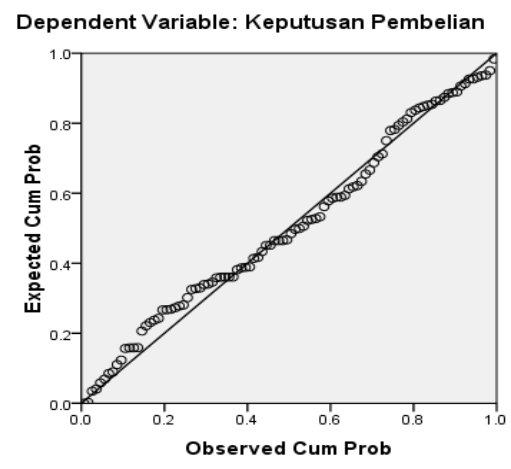

Fig.2. Graphic Of Normality Test

\section{Heteroscedasticity test}

From the Fig. 3. The Graphic of heteroscedasticity test output can be seen that there is no clear pattern, the dot does not accumulate, and the points spread above and below the number 0 on the $\mathrm{Y}$ axis, it can be concluded that there is no heteroscedasticity.

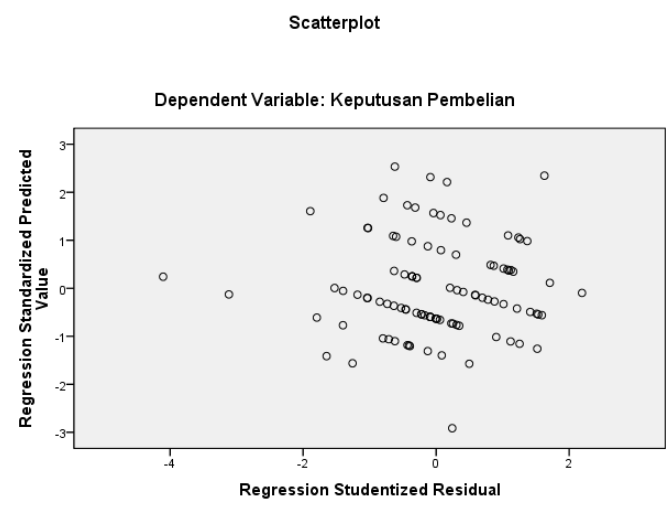

Fig.3. Graphic Of Heteroscedasticity Test

\section{Multicollinearity Test}

This test aims to test whether the regression model found a correlation between independent variables. A good regression model should not be correlated between independent variables. From Table 1. There is no symptom of multicollinearity in Facebook interaction, Instagram, Twitter, Line, WhatsApp and marketing of UMKM because each tolerance value is above 0.10 and also VIF value which is under 10 .

Table 1. Multicollinearity Test Results

\begin{tabular}{|l|c|c|}
\hline & Tolerance & VIF \\
\hline Facebook & 0.319 & 3.133 \\
\hline Instagram & 0.288 & 3.472 \\
\hline Twitter & 0.299 & 3.347 \\
\hline Line & 0.284 & 3.521 \\
\hline WhatsApp & 0.218 & 4.595 \\
\hline Women MSMEs & 0.342 & 2.925 \\
\hline
\end{tabular}

\section{B. Hypothesis Test}

\section{Multiple Linear Regression Analysis}

In the study of multiple linear regression analysis is used to test the hypothesis. Based on these results it can be interpreted:

- Constant (a) of -0,500 indicates the value of MSMEs marketing variable will remain -0.500 if all independent variables are zero.

- Facebook has a coefficient value of 0.332 , meaning that if the use of facebook upgraded one unit (100\%) then the marketing of MSMEs will also increase by 0.332 $(33.2 \%)$ with the assumption that other variables are fixed.

- Instagram has a coefficient of -0.166 , meaning if the use of instagram increased one unit $(100 \%)$ then the marketing of MSMEs will decrease by 0.166 (16.6\%) assuming other variables are fixed value.

- Twitter has a coefficient of 0.106 , meaning that if the use of twitter is increased one unit $(100 \%)$ then the marketing of MSMEs will also increase by 0.106 $(10.6 \%)$ with the assumption that other variables are fixed.

- Line has a coefficient value of 0.221 , meaning that if the use of line is increased one unit $(100 \%)$ then the marketing of UMKM will also increase by 0.221 $(22.1 \%)$ with the assumption that other variables are fixed. 
- Whatsapp has a coefficient value of 0.536 , meaning that if the use of whatsapp increased one unit $(100 \%)$ then the marketing of will also increase by $0.536(53.6 \%)$ with the assumption that other variables are fixed.

Table 2. Multiple Linear Regression Analysis

\begin{tabular}{|c|c|c|c|}
\hline Model & B & t & Sig \\
\hline (Constant) & -0.5 & -0.298 & 0.766 \\
\hline Facebook & 0.332 & 2.629 & 0.01 \\
\hline Instagram & -0.168 & -1.446 & 0.152 \\
\hline Twitter & 0.106 & 0.804 & 0.423 \\
\hline Line & 0.221 & 1.857 & 0.066 \\
\hline WhatsApp & 0.536 & 4.064 & 0 \\
\hline
\end{tabular}

2. Results of Multiple Linear Regression Analysis Equation Model II

Based on these results it can be interpreted:

- The constant (a) of 1.683 indicates the value of the purchase decision variable will remain at 1,683 if all independent variables are zero.

- Facebook has a coefficient value of 0.024 , meaning that if the use of facebook increased one unit (100\%) then the purchase decision will also increase by 0.024 $(2.4 \%)$ assuming other variables are fixed.

- Instagram has a coefficient value of 0.186 , meaning that if instagram usage is increased by one unit $(100 \%)$ then the purchase decision will increase to $0.186(18.6 \%)$ with the assumption that other variables are fixed.

- Twitter has a coefficient of 0.061 , meaning if the use of twitter is increased one unit $(100 \%)$ then the purchase decision will also increase by $0.061(6.1 \%)$ assuming other variables are fixed value.

- Line has a coefficient value of 0.155 , meaning that if the use of line is increased one unit $(100 \%)$ then the purchase decision will also increase by $0.155(15.5 \%)$ assuming other variables are fixed.

- Whatsapp has a coefficient value of 0.069 , meaning if the use of whatsapp increased one unit (100\%) then the purchase decision will also increase by 0.069 $(6.9 \%)$ assuming other variables are fixed.

- MSMEs For Marketing has a coefficient value of 0.423 , meaning that if UMKM marketing is increased one unit $(100 \%)$ then the purchase decision will also increase by $0.423(42.3 \%)$ with the assumption that other variables are fixed.

Table 3. Multiple Linear Regression Analysis Equation Model II

\begin{tabular}{|c|c|c|c|}
\hline Model & B & t & Sig \\
\hline (Constant) & 1.683 & 1.806 & 0.074 \\
\hline Facebook & 0.024 & 0.334 & 0.739 \\
\hline Instagram & 0.186 & 2.851 & 0.005 \\
\hline Twitter & 0.061 & 0.832 & 0.407 \\
\hline Line & 0.155 & 2.3 & 0.024 \\
\hline WhatsApp & 0.069 & 0.87 & 0.387 \\
\hline Women MSMEs & 0.423 & 7.379 & 0 \\
\hline
\end{tabular}

\section{Test Statistic F (F-test)}

$F$ test is used to see the influence of social media ie facebook, instagram, whatsapp, line, twitter and marketing MSMEs simultaneously to the purchase decision. it can be seen that the $\mathrm{F}$ test results show a significant value of 0.000 smaller than 0.05 . The results of this $F$ test indicate that the independent variables simultaneously have a significant influence on the dependent variable that is the purchase decision.

Table 4. Test Result F

\begin{tabular}{|c|c|c|c|}
\hline Model & df & F & Sig. \\
\hline Regression & 6 & 88.726 & $.000^{\mathrm{a}}$ \\
\hline Residual & 93 & & \\
\hline
\end{tabular}

\section{Test Statistic t (t-test)}

Based on Table 4. The results of regression test analysis states that both instagram, line and marketing of MSME partially have a significant effect on purchasing decisions. While other variables do not provide significant influence on purchasing decisions. Instagram has a significance value of $t$ $0.005<0.05$, meaninginstagram partially significant effect on purchasing decisions. Line has a significance value of $t$ $0.027<0.05$, artinyaline partially significant effect on purchasing decisions.

Table 5. Test Statistic t (t-test)

\begin{tabular}{|c|c|c|c|}
\hline Model & B & t & Sig. \\
\hline (Constant) & 1.683 & 1.806 & 0.074 \\
\hline Facebook & 0.024 & 0.334 & 0.739 \\
\hline Instagram & 0.186 & 2.851 & 0.005 \\
\hline Twitter & 0.061 & 0.832 & 0.407 \\
\hline Line & 0.155 & 2.3 & 0.024 \\
\hline WhatsApp & 0.069 & 0.87 & 0.387 \\
\hline Women MSMEs & 0.423 & 7.379 & 0 \\
\hline
\end{tabular}




\section{Coefficient of Determination $\left(R^{2}\right)$}

Based on Table 5, the magnitude of R Square is 0.851 , which means that $0.851(85.1 \%)$ of independent variables are able to describe or explain purchasing decisions. While the rest of $14.9 \%$ described or explained by other variables that are not included in the research model.

Table 6. Coefficient of Determination $\left(\mathrm{R}^{2}\right)$
\begin{tabular}{|c|c|c|c|}
\hline Model & $\mathrm{R}$ & R Square & Adjusted R Square \\
\hline 1 & 0.923 & 0.851 & 0.842 \\
\hline
\end{tabular}

\section{Path Analysis}

Path analysis is used to examine the effect of mediation on a research model through intervening variables. Intervention variable in this research is marketing of MSMEs. Based on regression equation II known that Instagram and Line significantly influence to buying decision. So then the researchers will test whether the Instagram and line effect on purchasing decisions through marketing of MSMEs. The following is the result of path analysis in this research.

Table 7. Test Result of Instagram Path Analysis Equation I

\begin{tabular}{|crrcc|}
\hline Model & R Square & Beta & t & Sig. \\
\hline Instagram & .359 & .599 & 7.402 & .000 \\
\hline
\end{tabular}

Dependent Variabel: The Marketing Of MSMEs

Table 8. Test Result of Instagram Path Analysis Equation II

\begin{tabular}{|cccrr|}
\hline Model & R Square & Beta & $\mathrm{t}$ & Sig. \\
\hline Instagram & & & & \\
The Marketing Of & .826 & .338 & 6.394 & .000 \\
MSMEs & & .665 & 12.594 & .000 \\
\hline
\end{tabular}

Dependent Variable: Buying Decision

Based on the output of SPSS in Table 6, the value of standardized beta Instagram on path analysis of equation I of 0.599 and significant value of 0.000 which means Instagram significantly influence the marketing of MSMEs. The value of the standardized coefficient beta 0.599 is the path or path value $\mathrm{p}_{2}$. At SPSS output equation II standardized beta value for Instagram of 0.338 and marketing MSME of 0.665. The standardized beta value of Instagram of 0.338 is the $p_{1}$ path value and the standardized value of marketing beta of MSMEs of 0.665 is the $\mathrm{p}_{3}$ point value. The value of $\mathrm{e} 1=$ 0.801 and the value of $\mathrm{e}_{2}=0.417$

The result of path analysis shows the magnitude of the direct effect $\left(p_{1}\right)$ is $0.338(33.8 \%)$ while the indirect effect is calculated by multiplying the indirect coefficient of $0.599 \mathrm{x}$ $0.665=0.398(39.8 \%)$. With these results it can be seen that the indirect effect of Instagram on buying decision is greater than its direct effect $(0.398>0.338)$.
Table 9. Line Test Results Line Equation Analysis I

\begin{tabular}{|crrrr|}
\hline Model & R Square & Beta & $\mathrm{t}$ & Sig. \\
\hline Line & .508 & .713 & 10.058 & .000 \\
\hline
\end{tabular}

Dependent Variable: The Marketing Of MSMEs

Table 10. Line Test Results Line Equation Analysis II

\begin{tabular}{|ccccc|}
\hline Model & R Square & Beta & $\mathrm{t}$ & Sig. \\
\hline Line & & .337 & 5.320 & .000 \\
The Marketing & .809 & .628 & 9.921 & .000 \\
Of MSMEs & & .600 \\
\hline
\end{tabular}

Dependent Variable: Buying Decision

Based on the output of SPSS in Table 8, the standardized value of beta line on equation path analysis $\mathrm{I}$ is 0.713 and significant value of 0.000 which means the line affects the marketing of MSMEs significantly. The value of standardized beta coefficient 0.713 is the path or path value $\mathrm{p}_{2}$. At SPSS output equation II standardized beta value for line is 0.337 and marketing of MSMEs is 0.628 .

The standardized beta line value of 0.337 is the 1 path value and the standardized beta value of marketing of MSMEs of 0.628 is the $\mathrm{p}_{3}$ point value. The value of $\mathrm{e}_{1}=$ 0.701 and the value of $e_{2}=0.437$. The result of path analysis shows the magnitude of the direct effect $\left(\mathrm{p}_{1}\right)$ is 0.337 $(33.7 \%)$ while the indirect effect is calculated by multiplying the indirect coefficient of $0.713 \times 0.628=0.448$ $(44.8 \%)$. The indirect effect of the line on purchasing decisions is greater than its direct effect $(0.448>0.337)$.

\section{Discussion}

Social media that is Facebook, Instagram, WhatsApp, Line, and Twitter have an effect on the marketing of UMKM. These mean that the physical surrounding like location, the store as well as the social surrounding like characteristics and interactions with others. The reason might be that the Smartphone is worthy enough, to pay for a little higher for a Smartphone. Most previous studies focused on simultaneously making simultaneously.

Facebook, Instagram, WhatsApp, line and twitter and MSMEs marketing have an effect on purchasing decision. Family purchase behavior is a research field of special interest for firms and institutions. Consumers create added value through collaboration and social interactions on the internet. They support business through the co-creation of value via their social interactions. By reviewing the relevant literature, it is not that the definitions of electronic marketing (E-Marketing) vary according to each author's point of view, background and specialization. Everyday life, and use digital devices instead of going to physical shops.

Test results in Path Analysis showed that Instagram influence on consumer purchasing decisions through marketing by women SMEs in North Sumatra. Nowadays, most of the businesses are related to electronically especially internet. The essence of the "product" element in e-commerce corresponds partly to the essence of the traditional element concept. 
Path analysis in this research is only done for social media that is Instagram and Line because on result of regression model equation II proved that Facebook, WhatsApp, and twitter have no significant effect to purchasing decision. The advertisement server who technologically delivers the advertisement and tracks statistics, and advertising affiliates who do independent promotional work for the advertiser. It is much easier for customers to find substitutes from competitors on the internet because of the minimum effort a person has to make to get to another website. Maintenance costs due to a constantly evolving environment, higher transparency of pricing and increased price competition, and worldwide competition through globalization.

\section{CONCLUSIONS AND RECOMMENDATIONS}

\section{A. Conclusions}

Based on the data analysis and discussion of the results of the analysis, the following conclusions can be drawn:

- Social media is Facebook, and WhatsApp have a significant effect on marketing of MSMEs. However, Instagram, Line and Twitter has no significant effect on the marketing of MSMEs.

- Social media such as Instagram and Line and the marketing of MSMEs have a significant effect on buying decision. However, Facebook, WhatsApp, and Twitter have no significant effect on buying decision.

- Social media such as Instagram and line have an effect on buying decision through marketing of MSMEs.

\section{B. Recommendations}

Based on the discussion and the conclusion of the study, it is advisable:

- The results of research show that the use of Instagram and Line can influence directly or indirectly (through marketing) to the buying decision. It is recommended for the perpetrator of woman MSMEs to continue to do marketing by using Instagram and also line.

- For subsequent research it is hoped that the next researcher can use other social media that researchers do not use in this research model such as Youtube, Path, BBM.

\section{REFERENCE}

[1] Republik Indonesia, Kementerian Komunikasi Dan Informatika; (2014, 1124$)$.

Https://Kominfo.Go.Id/Content/Detail/4286/Pengguna-InternetIndonesia-Nomor-Enam-Dunia. Retrieved 08 27, 2017, From Https://Kominfo.Go.Id:

Https://Kominfo.Go.Id/Content/Detail/4286/Pengguna-InternetIndonesia-Nomor-Enam-Dunia/0/Sorotan_Media

[2] Sagala, C., Destriani, M., Putri, U. K., \& Kumar, S. (2014). Influence Of Promotional Mix And Price On Customer Buying Decision Toward Fast Food Sector: A Survey On University Students In Jabodetabek (Jakarta, Bogor, Depok, Tangerang, Bekasi) Indonesia. International Journal of Scientific And Research Publications, Volume 4 Issn 2250-3153 , 1-7.
Malviya, S., Saluja, M. S., \& Thakur, A. S. (2013). A Study On The Factors Influencing Consumer's Purchase Decision Towards Smartphones In Indore. International Journal of Advance Research In Computer Science And Management Studies Volume 1, Issue 6 Issn: 2321-7782 (Online), 14-21.

[4] Lin, L. Y., \& Shih, H. Y. (2012). The Relationship Of University Student's Lifestyle, Money, Attitude, Personal Value And Their Purchase Decision. International Journal Of Research In Management Issue2, Vol. 1 Issn 2249-5908, 19-37.

[5] Barlés-Arizón, M. J., Andrés, E. F., \& Salinas, E. M. (2013). Purchase Decision-Making In The Couple. Conflict-Solving Tactics. International Journal Of Business And Social Science Vol. 4 No. 6, 28-43.

[6] Hajli, M. N. (2014). A Study Of The Impact Of Social Media On Consumers. International Journal Of Market Research Vol. 56 issue 3, 387-404.

[7] El-Gohary, H. ( 2010). E-Marketing - A Literature Review From A Small Businesses Perspective. International Journal of Business And Social Science Vol. 1 No. 1; 214-244.

[8] Taherdoost, H., \& Jalaliyoon, N. (2014). Marketing Vs EMarketing. International Journal Of Academic Research In Management (Ijarm) Vol. 3, No. 4, Issn: 2296-1739, 335-340.

[9] Sathya, P. (2015). A Study On Digital Marketing And Its Impact. International Journal Of Science And Research (Ijsr) Issn (Online): 2319-7064, 78-96.

[10] Salehi, M., Mirzaei, H., Aghaei, M., \& Abyari, M. (2012). Dissimilarity Of E-Marketing Vs Traditional Marketing. International Journal Of Academic Research In Business And Social Sciences Vol. 2, No. 1 Issn: 2222-6990, 510-515.

[11] Pogorelovaa, E. V., Yakhneevaa, I. V., Agafonova, A. N., \& Prokubovskaya, A. O. ( 2016). Marketing Mix For ECommerce. International Journal Of Environmental \& Science Education, Vol. 11, No. 14, 6744-6759, 1-16.

[12] Anusha, G. (2016). Effectiveness Of Online Advertising. International Journal Of Research Granthaalayah, 14-21.

[13] Schwarzl, S., \& Grabowska, M. (2015). Online Marketing Strategies: The Future Is Here. Journal Of International Studies Vol. 8, No 2, 187-196

[14] Gangeshwer, D. K. (2013). E-Commerce Or Internet Marketing: A Business Review From Indian Context. International Journal Of U-And E-Service, Science And Technology Vol.6, No.6, 187194. 